\title{
Novel biomarkers for early diagnosis of acute kidney injury after cardiac surgery in adults
}

\author{
Aleksandar Gavrić, Jurij Matija Kališnik \\ University Medical Center, Ljubljana, Slovenia
}

Kardiochirurgia i Torakochirurgia Polska 2016; 13 (1): 31-38

\begin{abstract}
Acute kidney injury after cardiac surgery with cardiopulmonary bypass is a common and serious complication and it is associated with increased morbidity and mortality. Diagnosis of acute kidney injury is based on the serum creatinine levels which rise several hours to days after the initial injury. Thus, novel biomarkers that will enable faster diagnosis are needed in clinical practice. There are numerous urine and serum proteins that indicate kidney injury and are under extensive research. Despite promising basic research results and assembled data, which indicate superiority of some biomarkers to creatinine, we are still awaiting clinical application.

Key words: biomarkers, AKI, surgery, NGAL, KIM-1.
\end{abstract}

\section{Introduction}

Cardiac surgery with cardiopulmonary bypass (CPB) is the second most common cause of acute kidney injury (AKI) among hospitalized patients [1] which remains associated with high morbidity and mortality, despite progress in medical care [2]. The most serious complications of AKI include an increased risk to infections, development of chronic kidney disease, extrarenal organ damage, an increased rate of hospital readmission and acute haemodialysis requirement $[3,4]$. Despite RIFLE and AKIN diagnostic criteria - that are based on serum creatinine and urine output - help diagnosing AKI, we need a reliable tool to differentiate between true parenchymal and pre-renal azotaemia in clinical practice as RIFLE and AKIN signal AKI presence once a decline in glomerular filtration rate is already present [2]. Patients who double their serum creatinine or need acute dialysis have a 2 - to 5 -fold higher risk of death [5]. It is estimated that even patients who recover kidney function remain at an increased risk of chronic kidney disease (CKD) and premature death. The estimated rate of CKD after AKI was 6.2 per 100 person-years [6].

Acute kidney injury after the cardiac surgery is a complex and multifactorial process that is yet to be fully under-

\section{Streszczenie}

Ostre uszkodzenie nerek po operacji kardiochirurgicznej z użyciem bypassu sercowo-płucnego to częsta i poważna komplikacja powiązana z wyższym ryzykiem powikłań i śmiertelnością. Rozpoznania ostrego uszkodzenia nerek dokonuje się na podstawie stężenia kreatyniny w surowicy, które wzrasta w ciągu kilku godzin do kilku dni po początkowym urazie. Dlatego też w praktyce klinicznej konieczne są nowe markery umożliwiające szybszą diagnozę. Istnieje wiele rodzajów białek, których obecność w moczu i surowicy wskazuje na uszkodzenie nerek. Prowadzone są nad nimi intensywne badania. Pomimo obiecujących wyników badań wstępnych i zebrania danych sugerujących wyższość niektórych biomarkerów w porównaniu z kreatyniną, wciąż czekamy na ich zastosowanie kliniczne.

Słowa kluczowe: biomarkery, AKI, chirurgia, NGAL, KIM-1.

stood. So far, at least six major injury pathways have been identified: reperfusion, ischemia, metabolic factors, neurohumoral activation, inflammation and oxidative stress [7] Some biomarkers can be increased due to the production in extra-renal tissues as it was found in animal models for interleukin-18 (IL-18) and NGAL. The secretion from immune cells and extra-renal tissues into the bloodstream can increase in response to systemic inflammation during sepsis and after major surgery, even in the absence of AKI. This should be considered when elevated biomarker levels are evaluated in critically ill and postoperative patients [8]. Most of the novel biomarkers are markers of structural injury [9]. To improve lag in diagnosis and account for both structural and functional kidney impairment in the very early phases, an increased interest has been lately aroused in the use of combinations of biomarkers [10].

\section{Clinical need of biomarkers for early detection of acute kidney injury}

Biochemical markers of myocardial injury have undergone profound changes for the past 50 years. Witnessing 
the progressive development of biomarkers in cardiology where we moved from aspartate amino transferase measurement to the present use of troponins which dramatically improved diagnosis, treatment and survival after cardiac injury. The development of kidney diagnostic markers have been far less profound. Creatinine is still used as an indicator of kidney function but not of the parenchymal kidney injury. The serum creatinine concentration does not change until around $50 \%$ of kidney function is lost. In addition, factors such as age, muscle mass, medications, sex and hydration status also affect creatinine levels [8]. In contrast to myocardial infarction, AKI patients remain largely asymptomatic, so establishing the diagnosis in this increasingly common disorder currently hinges hourly diuresis and potassium levels estimation as well as on functional biomarkers such as serial creatinine measurements [11]. One reason for slow progress in the methods for the early laboratory diagnosis of AKI has been the reliance and simplicity of serum creatinine determination. The other lies in inherent inability of creatinine and other markers to distinguish between normal renal function, AKI, chronic kidney disease and transient azotaemia with dehydration or pre-existing kidney disease deterioration reinforced by an acute superimposed kidney injury. Additionally, the rise of serum creatinine following acute injury is delayed by several hours to days, profoundly hindering the prompt initiation of potential therapies or even preventive measures [3].

\section{Novel biomarkers}

There are many new molecules under research for analysing their potential for early detection of the AKI [2]. Proteins such as neutrophil gelatinase-associated lipocalin (NGAL), IL-18, kidney injury molecule-1 (KIM-1), liver-type fatty acid binding protein (L-FABP), cystatin C (cysC), tissue inhibitor of metalloproteinase-2 (TIMP-2) and insulin like growth factor binding protein 7 (IGFBP7) have been recognized as promising biomarkers of AKI based on animal and early human studies [12]. Biomarkers under research can be measured in plasma, serum and urine. Biomarkers in the urine may be more specific and sensitive for the detection of the kidney injury as tubular cell proteins are released into the urine in response to ischemic or nephrotoxic injury. Urine is also more likely to contain biomarkers arising from the kidney. On the other hand, urine samples are likely to undergo protein degradation, also urine biomarker concentrations can be affected by urine flow rate changes. Serum samples can be obtained also in anuric patients and serum biomarkers tend to be more stable. The disadvantage of serum biomarkers is that they can reflect systemic response to certain diseases and CPB bypass, rather than specific kidney dysfunction. Despite the promising findings at the level of basic research, this knowledge has not been yet transferred to clinical practice as agreement regarding the appropriate thresholds for diagnosis of AKI is yet to be confirmed. Clinical use of novel biomarkers will most likely remain limited until prospective multicentre studies demonstrate their utility [9].

\section{Neutrophil gelatinase-associated lipocalin}

Neutrophil gelatinase-associated lipocalin (NGAL) concentration in renal proximal tubules increases rapidly after renal ischemia-reperfusion injury and, as such, it has been extensively investigated as a novel biomarker for AKI [7]. It was demonstrated that AKI causes and increase in NGAL mRNA and protein expression also in distant organs such as the lungs and liver [13]. Few studies in animal models concluded that NGAL is one of the most upregulated genes and proteins in the kidney very early after the kidney injury [3]. Tubule epithelial cells that were undergoing proliferation and regeneration were identified as the site of the highest NGAL protein expression [3]. This may suggest the NGAL role in the repair process. Urine NGAL is mostly derived from the distal nephron epithelial cells while plasma NGAL originates from damaged tubules via back leak and also from extrarenal organs [14]. It remains unclear to what extent non-renal NGAL sources might adversely affect the diagnostic accuracy. Another limitation of the NGAL is the effect of the chronic kidney disease (CKD) on the accuracy of NGAL for AKI prediction. It is known that NGAL levels in patients with stable CKD (stable renal function over time) are similarly low as in normal controls. Progressive CKD (decline in eGFR of $\geq 5 \mathrm{ml} / \mathrm{min} / 1.73 \mathrm{~m}^{2}$ within one year based on at least three readings or $\geq 10 \mathrm{ml} / \mathrm{min} / 1.73 \mathrm{~m}^{2}$ within five years) may display higher concentrations. The lack of a standard AKI definition, the lack of precisely identified cut-off values and differences in clinical assay characteristics are additional limitations preventing widespread use of NGAL in clinical practice [3]. Another important point to bear in mind is the fact that the success of NGAL as also some other biomarkers mentioned in the article is based on the studies conducted in carefully selected homogenous populations. Regarding that many other conditions such as age, anaemia, cancer and inflammatory conditions (NGAL is acute phase reactant) can affect NGAL concentration makes NGAL performance as a reliable predictive biomarker of AKI poorer in real-life patients with comorbidities or in critically-ill patients $[15,16]$ and these patients are common in the field of the cardiovascular surgery. Despite these limitations, positive results regarding NGAL capabilities to detect AKI early and reliably are accumulating.

Recently, a Translational Research Involving Biomarkers and Endpoints (TRIBE) study assessed the value of NGAL in 1219 adults [17] and 311 children [18] undergoing cardiac surgery. This has been the largest study of its kind so far. In both populations NGAL urine and plasma concentrations were the highest within 6 hours after surgery and showed improved risk prediction [3]. Krawczeski et al. [19] found that urine NGAL was the only biomarker - of all studied biomarkers in their study - with a predictive value as early as $2 \mathrm{~h}$ postoperatively while other biomarkers had no value at this time after surgery. In the same study, the predictive value of urine NGAL was exceptional with AUC $>0.9$ and independent of the timing of its measurement [3]. Another study found AUC value of NGAL for AKI detection 24 hours after the surgery to be 0.96 [20]. On the other hand, urine 
levels of NGAL can be increased in conditions other than AKI such as is the case with serum NGAL. Urine NGAL is for instance increased in immunoglobulin A nephropathy (IgAN) [21]. Moreover, urinary NGAL seems to be increased also in acute urinary tract infections [22]. Urinary kidney injury molecule 1 (KIM-1), another biomarker described in our paper was not shown to be a helpful biomarker in the setting of the urinary tract infection.

Recent research has provided valuable data about cutoff values. Haase-Fielitz et al. demonstrated that plasma NGAL levels $>150 \mathrm{ng} / \mathrm{ml}$ taken on arrival in the intensive care unit had a $76 \%$ sensitivity and $91 \%$ specificity for predicting AKI [7]. One study demonstrated that at a cut-off value of $136 \mathrm{ng} / \mathrm{ml}, 3$ hours post-CPB NGAL demonstrated a 73.9\% sensitivity and $89.3 \%$ specificity in detecting the need for early medical intervention, which included diuretics or dopamine infusion. In this study RIFLE criteria were used for AKI identification [7]. In the prospective, large, multicentric observational cohort study, plasma NGAL had the strongest ability to predict the progression of AKI. Patients in the fifth quintile (plasma NGAL > $323 \mathrm{ng} / \mathrm{ml}$ ) had an 11-fold odds ratio of AKI progression in the unadjusted analysis. In the same study the combination of urine and plasma NGAL provided the highest AUC (0.79) to forecast AKI progression [23]. Based on the available data, it can be concluded that both, urine and plasma NGAL are predictive of AKI and its severity. However, one of the problems of published studies is lack of following standard guidelines for reporting studies of diagnostic accuracy. Such guidelines should be considered to minimize study errors and heterogeneity in the reported predictive NGAL value, the time point of measurement, assay used and conditions of sample storage [3].

\section{Kidney injury molecule-1}

Kidney injury molecule-1 (KIM-1) is an immunoglobulin (Ig) superfamily transmembrane receptor that is expressed in the tubules in the setting of kidney injury to aid the removal of necrotic and apoptotic debris. KIM-1 is expressed at a low level in normal kidneys, but after ischemic injury, upregulation of the protein is increased in proximal tubules [24]. Animal studies have shown that the levels of urinary $\mathrm{KIM}-1$ increase in models of ischemic AKI, sometimes without adjuvant creatinine elevation [25]. KIM-1 was markedly elevated in dedifferentiated proximal tubular cells of ischemic rat kidney. Urinary KIM-1 levels are related to tubular KIM-1 expression in experimentally induced renal disease [24]. KIM-1 levels are measured using ELISA. In multiple models urinary KIM-1 performed better than serum creatinine ( $\mathrm{sCr}$ ) and blood urea nitrogen (BUN). The AUC for KIM-1 was 0.91-0.99 when compared with 0.79-0.9 for BUN and 0.73-0.85 for sCr. Unfortunately, these excellent results could not be reiterated in human studies so far. In one study KIM-1 [26] did not perform better than $\mathrm{sCr}$ or urine output in the prediction of renal replacement therapy or death, with an AuROC of only 0.61. A 2009 report described KIM-1 measurements from 90 adult cardiac surgery patients; 36 of them developed AKI [11]. An ROC curve for urinary KIM-1 drawn immediately after surgery had an AUC of 0.68. Another finding of this study was that combining multiple AKI biomarkers improved the overall predictive value [11]. A recent study of 123 adults who underwent cardiac surgery illustrated that preoperative urinary KIM-1 levels were able to predict the development of AKI with AUC of 0.67 [23]. TRIBE study did not come to the same conclusion as preoperative KIM-1 levels were not significantly different between those who did and did not develop AKI. In the adults urinary $\mathrm{KIM}-1$ levels of $>1.18 \mathrm{ng} / \mathrm{ml}$ were associated with a $4.7-$ fold risk of AKI [12]. A systemic review revealed that KIM-1 is an efficient urinary biomarker of AKI within 24 hours after kidney injury when aetiology was ischemic acute tubular necrosis. A meta-analysis of 11 studies revealed that urinary KIM-1 showed the best performance characteristics in patients after cardiac surgery 2-12 hours after CPB, however, the diagnostic accuracy was better in infants and children than in adults. This is probably due to significant comorbid conditions, such as atherosclerosis, hypertension and diabetes mellitus being prevalent in adults [24]. When KIM-1 was combined with L-FABP, ability to predict AKIN 3 or death was high with AUC of 0.93 , a positive predictive value of $63 \%$ and sensitivity of $77 \%$ [10]. Despite numerous analyses being carried out, the small study populations and heterogeneous patient type, the clinical applicability of KIM-1 as an biomarker for early AKI detection needs to be validated in larger studies with more homogenous study population [24].

The concentration of KIM-1 is also affected by other conditions such as sepsis and use of contrast media. Age is another factor that affects expression of KIM-1. In addition, the urinary concentration may be influenced by common diseases such as diabetes mellitus, hypertension and atherosclerosis [24]. KIM-1 and NGAL are suggested to play a role in the carcinogenesis of renal cell carcinoma. When used in combination, urinary KIM-1 and NGAL can serve as predictors of kidney cancer [27].

\section{Interleukin-18}

Interleukin-18 (IL-18) is a proinflammatory cytokine with a molecular weight of $18 \mathrm{kDa}$. The major source of production is renal tubular cells and macrophages. IL-18 is just as NGAL, specific to kidney tubules. Its preoperative levels are low and increase in patients who develop AKI [20]. IL-18 is up-regulated in response to ischemic reperfusion injury. It is specific to the renal tubules [28]. It has been shown in animal studies that inhibiting IL-18 in mice decrease the severity of ischemic AKI [11]. Another animal model demonstrated significant increases in IL-18 in whole kidneys after experimentally induced AKI. Mice with ischemic AKI were found to have elevated urinary levels of IL-18 [8]. TRIBE-AKI study confirmed that higher IL-18 levels were associated with a higher risk of dialysis, longer length of ICU stay, longer hospitalization and death [11]. Three studies with patients undergoing CABG [8] involving a total of 258 patients showed that urinary IL-18 had a moderate predictive performance for AKI (AuROCs from 0.53 to 0.66 ) 
at post-CABG ICU admission. IL-18 levels may represent a non-specific marker of bypass-associated systemic inflammation rather than tubular damage, because urinary IL-18 correlated with the duration of CPB [29]. In a small study with 100 patients urine IL-18 appeared to be superior to creatinine in early detection of AKI. It also performed better at differentiating pre-renal from intrinsic tubular AKI. In the same study however, NGAL performed better in early detection of AKI diagnosis [20]. In a study that compared 32 urinary biomarkers IL-18 was the best predictor of the primary outcome of worsening AKI or death as well as the secondary outcome of AKIN stage 3 or death [10]. In combination with KIM-1, AUC to predict AKIN 3 or death was 0.93 . IL-18 excellently performed in prediction of development of severe AKI or death within 30 days after the surgery with AUC of 0.89 [10]. Results of a multicentre, prospective observational cohort study showed that urinary IL-18 is a promising biomarker in its ability to predict the worsening of $A K I$ at the time of creatinine-based diagnosis of AKI [23]. IL-18 levels have been observed to correlate with mortality in patients not only with AKI but also infections, hepatitis, malignancies and SLE. Serum IL-18 elevation correlates with cardiovascular, cerebrovascular and peripheral vascular events in patients on haemodialysis [30].

\section{Cystatin C}

Cystatin C (CysC) is a $13 \mathrm{kDa}$ proteinase inhibitor, formed in all cells with a cell nucleus that enters the proximal tubules by glomerular filtration. The protein is reabsorbed by the healthy proximal tubular cells and in disease free individuals only minimal concentrations are found in urine [8]. A study with 72 patients (34 developed AKI) showed urinary CysC ROC curve to be 0.705 for the immediate post-operative time point [31]. A recent study published by Ghonemy et al. presented optimistic results for CysC. Plasma CysC measurement in patients with AKI was significantly higher at 6 hours after surgery. The sensitivity and specificity of NGAL 3 hours after CPB was $94.1 \%$ and $93.9 \%$, respectively, while plasma CysC sensitivity and specificity was $54.7 \%$ and $72.7 \%$. In a small study with 50 patients, NGAL sensitivity and specificity 6 hours after CPB was $98.1 \%$ and $91.9 \%$, while CysC performance was poorer; $75.2 \%$ and $75.8 \%$. Authors concluded that plasma NGAL and plasma CysC may be considered as early predictors of AKI after CPB operations [32]. In another study, patients with AKI had higher CysC levels over all measurement time points; the earliest predictor of AKI was seen at the end of operation (time T4). So the conclusion was that CysC values measured immediately at the end of the operation provide an early indication of the possible onset of AKI but the predictive values depend on the AKI definition. A study with 100 patients after CPB cardiac surgery in adults showed very good predictive capacity of urinary CysC upon arrival at the ICU with AUC of 0.83 [31]. Royakkers et al. came to different conclusions in a larger study with 150 patients. CysC was a poor biomarker of AKI in the first 24 hours after cardiac surgery [32]. Another study, a prospective, single centre study with 70 patients, found that early post-op serum CysC increase appears to be a moderate biomarker in the prediction of AKI. A preoperative and intraoperative CysC increase has only a limited diagnostic and predictive value [31]. TRIBE-AKI showed surprising results, serum creatinine detected more cases of AKI than CysC: $35 \%$ develop a $\geq 25 \%$ increase in serum creatinine, whereas only $23 \%$ had a $\geq 25 \%$ increase in CysC. The conclusion of this large, multicentre study was that CysC was less sensitive for AKI detection compared with creatinine but the presurgical CysC level was a stronger predictor of AKI than the presurgical creatinine of eGFRCr (glomerular filtration rate estimated from creatinine) [17]. Two prior studies did not demonstrate a clear advantage for serum CysC in predicting AKI following adult cardiac surgery [33]. In the study by Wald et al., a modest association between CysC levels and AKI development was noted with AUC for CysC levels preoperatively of 0.67 and 2 hours after CPB of 0.68 . In the patients with baseline CKD, preoperative plasma CysC did not differ among patients with and without AKI, however, 2 hours post CPB CysC values were significantly higher in patients who developed AKI [34]. Koyner et al. in a study with adult cardiac surgery patients showed no significant difference between plasma CysC values of those with and without AKI 6 hours after surgery. Another finding of this study was that CysC rose later than creatinine in patients who developed AKI [31].

The role of urinary CysC as a biomarker of cardiac surgery-associated AKI is controversial with small studies demonstrating mixed results its role remains questionable. It can be recognized as an additional biomarker in the panel of novel biomarkers for AKI diagnosis. There are still data that support the utility of urinary CysC in other clinical settings. Critical illness and nephrotoxin-associated AKI are such examples [35]. In one study [36], plasma CysC was shown to be a good predictor for AKI in patients after acute myocardial infarction. Another published paper demonstrated a correlation between serum CysC and AKI in patients with major burns [37]. In an article with only abstract being available in English, researchers found an association between serum CysC and the metabolic syndrome [38].

\section{Tissue inhibitor of metalloproteinase-2 and insulin like growth factor binding protein 7}

Both, tissue inhibitor of metalloproteinase-2 (TIMP-2) and insulin like growth factor binding protein 7 (IGFBP7) are involved in G1 cell cycle arrest of renal tubular cells during the early period of cell injury caused by ischaemic or inflammatory processes [39]. Data about urinary TIMP-2 and IGFBP7 being early biomarkers of AKI are accumulating. Wetz et al. [39] conducted a study with 42 patients undergoing CABG. AKI was defined by applying KDIGO classification. In this study concentrations of urinary TIMP-2 were multiplied by IGFBP7. The conclusion of the study was that concentration of [TIMP-2] $\times$ [IGFBP7] has diagnostic potential to identify patients at increased risk of AKI after CPB on the first postoperative day (8:00 AM on the first postoperative day), however at earlier time points the difference in [TIMP-2] $\times$ [IGFBP7] concentrations between KDIGO 0 and KDIGO 1 and 2 was not 
significant. Researchers did not identify AKI risk 4 hours after CPB, while Meersch et al. [40] did. Authors concluded that this difference in results could be due to different risk groups of patients. In the study by Wetz et al., patients had a low risk of AKI. In the paper published by Meersh et al., there were 50 patients undergoing CPB cardiac surgery and all at a high risk of $A K I$ development including having CKD. Relying on changes of the concentration of urinary [TIMP-2] $\times$ [IGFBP7] was significantly higher in patients with AKI at 4 hours after CPB. In addition, another finding from the same research groups was that [TIMP-2] $\times$ [IGFBP7] urinary concentration predicted renal recovery from AKI after cardiac surgery. This biomarker was also studied in paediatric populations and in AKI of aetiologies other than CPB-induced AKI. In a study with paediatric population who developed AKI due to different aetiologies [41], urinary [TIMP-2] × [IGFBP7] had a good diagnostic performance in predicting mortality and a moderate performance in predicting requirement for RRT. In the same study, researchers also found that urinary [TIMP-2] × [IGFBP7] values in non-AKI patients are largely independent of age. As other biomarkers, also values of [TIMP-2] × [IGFBP7] are affected with non-renal clinical settings. Bell et al. [42] found that that [TIMP-2] × [IGFBP7] were significantly elevated in diabetic patients.

\section{Liver fatty acid-binding protein}

Fatty acid binding proteins are small (15 kDa) cytoplasmic proteins expressed in tissues with active fatty acid metabolism. Their function is facilitation of long-chain fatty acid transport, regulation of gene expression and reduction of oxidative stress. In the human kidney, liver fatty acid-binding protein (L-FABP) is expressed in the proximal tubules as the major source of energy metabolism. It binds free fatty acids and has a renoprotective role [12]. L-FABP is undetectable in healthy urine. Under ischemic conditions, tubular L-FABP gene expression and proximal tubular re-absorption of L-FABP is reduced [43]. From the prospective study of 40 children undergoing cardiac surgery ( 21 developed AKI), urinary L-FABP was a powerful independent risk indicator for AKI. The AUC was 0.81 at 4 hours after CPB [44]. With AUC of 0.67 and 0.85 for the prediction of AKI progression and for the prediction of death in patients after cardiac surgery who developed AKI after the procedure, L-FABP is a moderate predictor of AKI-related complications [10]. L-FABP is a promising candidate to become a biomarker for AKI detection, but this prediction is based on studies that included patients with contrast nephropathy, patients with chronic kidney disease and pharmacologically induced AKI. Further studies are needed with patients after CPB cardiac surgery [44].

\section{Other biomarkers \\ Klotho}

Originally, Klotho was identified as the product of an antiaging gene in 1997 and has become a major focus in the renal field for the past 5 years. In the mammalian kidney, Klotho is expressed at two sites; distal convoluted tu- bules and proximal convoluted tubule. Two Klotho proteins were identified: membrane and soluble secreted protein. It has been proposed that downregulation of renal Klotho in AKI is a general phenomenon following acute kidney insults such as ischemia, oxidative stress and exposure to nephrotoxins. Thus, Klotho is considered as an early biomarker of $\mathrm{AKI}$ and it has potential of becoming a therapeutic agent. In a rodent model, Klotho levels were sustainably decreased 3 hours after the induced AKI by ischemia-reperfusion injury, advocating that renal Klotho is one of the earliest biomarkers of kidney injury. Another animal study has shown downregulation of Klotho in AKI regardless of aetiology [45]. At the moment we do not have data regarding the role of Klotho as a biomarker for AKI from human studies [45].

\section{Roundabout protein 4}

Roundabout protein 4 (Robo4) is an endothelial-expressed transmembrane receptor and regulator of cell activation. Roundabout proteins are a family of transmembrane receptors originally identified for their role in axon guidance during development of the nervous system. So far, four receptors have been identified. Robo4 was described as an endothelial expressed gene. One study investigated the correlation between Robo4 levels and AKI development after CPB cardiac surgery. Plasma levels of Robo4 were significantly higher in patients 2 hours post-operatively compared with levels prior to surgery. In the same study, they found a positive association between urine NGAL levels and plasma Robo4 levels 2 hours after the surgery. In addition, Robo4 levels were significantly greater in the patient group with plasma NGAL levels of $>150 \mathrm{ng} / \mathrm{ml}$. Elevated post-operative plasma Robo4 levels correlated significantly and positively with plasma and urine NGAL levels. The association maintained when patients were divided into those with and without AKI. There were no association between creatinine and Robo4 [46].

\section{Semaphorin $3 A$}

Semaphorin 3A is another promising biomarker for early AKI detection. It is highly expressed after AKI in mice and humans, but its pathophysiological role is unknown. So far, conducted research revealed that semaphorin $3 \mathrm{~A}$ mediates tubular epithelial cell apoptosis and inflammation and that in non-diseased kidneys this molecule is expressed in renal collecting ducts and podocytes [47]. Semaphorin 3A was able to detect late-onset $\mathrm{AKI}$ and $\mathrm{AKI}$ progression in critically ill patients [48], however AUC to detect established AKI was lower in comparison with IL-18, NGAL and L-FABP. In one study, urine semaphorin $3 A$ increased 2 hours after CPB and peaked at 6 hours, its concentration decreased to a non-significant level at 12 hours after CPB. Predictive power for diagnosis of AKI demonstrated as AUC was 0.88 at 2 and 0.81 at 6 hours after CPB [49].

\section{Netrin-1}

Netrin-1 has been recently identified as a novel tubular injury biomarker with a potential to diagnose AKI 
much earlier than existing biomarkers of kidney injury. It is a laminin-related secreted protein highly induced after acute and chronic kidney injury [50]. Tu et al. showed that urinary netrin-1 increased significantly one hour in septic patients with AKI. In the same study [51], urinary KIM-1 was associated with poor prognosis. To date only one study [52] with netrin-1 investigation for AKI detection after cardiac surgery has been published. In a study with 26 patients, netrin-1 peaked at 6 hours after CPB in patients who developed AKI. In addition, in the same study netrin-1 correlated with duration, severity of AKI and with duration of the hospitalisation.

\section{Cysteine-rich protein 61}

Cysteine-rich protein 61 (CYR61) is an extracellular matrix molecule. Preclinical studies showed that the CYR61 concentration is increased at sites of inflammation, wound healing accompanied with chronic inflammation and tissue injury [53]. One study performed on mice in which unilateral kidney ischemia reperfusion injury was induced, proposed that stoppage of CYR61 stops inflammatory damage associated with ischemic AKI. Another study on mice revealed rapid up-regulation of the CYR61 gene in kidney after induced renal ischemia. Induction of the protein was detected within one hour following ischemia. Currently we lack data about CYR61 values in humans or its changes in kidney injury [54].

\section{Discussion}

The non-existence of a sensitive, specific and early marker of AKI has been a limiting factor in fast diagnosis of AKI and its treatment. Although serum creatinine is the standard marker, it has numerous limitations, with its dependence on age, sex and muscle mass being most impactful. Existence of chronic renal failure also affects creatinine levels. These are main reasons for inability of creatine level changes to detect time and type of renal injury [24]. There are many biomarkers for detection of early kidney injury undergoing scientific and clinical research with NGAL being the most promising. However, NGAL is still not routinely used in clinical practice because overall results are inconsistent, with variations in sample collection protocols, procedure type and patient population. Definition of AKI is still not standardised [7]. Regarding diagnostic usefulness of NGAL and other novel biomarkers, authors vary in their opinions from very optimistic to negative [2]. There are few explanations why the results are so broad. Biomarkers are investigated in different clinical settings, paediatric post-cardiac bypass, to patients with septic shock, adults after cardiac surgery with CPB. Timing of renal injury is not well known in all settings. Furthermore, AKI is not the only cause of raise of biomarker levels. Some of these are also associated with sepsis, diabetic nephropathy, systemic lupus erythematosus, haemolytic uremic syndrome and inflammation [2]. A recently published study assessed urinary TIMP-2 and IGFBP7, NGAL and cystatin-C as AKI predictors researching the association of non-renal fac- tors [42]. The conclusion of their study was that neither of these urinary biomarkers predicted AKI within 12 to 48 hours in general ICU patients. In addition, values of [TIMP-2] $\times$ [IGFBP7] in the study group were significantly elevated in diabetic patients and there was an independent association between sepsis and higher NGAL and CysC urine concentrations. The latter connection is not new. A lot of patients after cardiac surgery have comorbidities, diabetes being one of the most common. Findings from the [42] are an important reminder that interpretation of the results must be done on a case-by-case basis taking patient's comorbidities into consideration. Some markers are increased in patients with chronic kidney disease. We do not know yet how described biomarkers behave in patients with CKD. An important obstacle is also the fact that AKI is not a single disease but a complex syndrome with multiple aetiologies. This was shown by studying TIMP-2 and IGFBP7. In one study, IGFBP7 was superior to TIMP-2 in surgical patients, while TIMP-2 performed better in sepsis-induced AKI [55]. Differences in these results underlie mechanistic differences between diverse aetiologies of AKI. Last but not least, many studies focus on the belief that biomarker rise without a rise in serum creatinine indicates AKI, which increases sensitivity at the expense of specificity. This is because we lack a gold standard to diagnose AKI and difficulty to make a distinction between intrinsic renal damage (histological AKI) and physiological decrease in renal perfusion (functional AKI) in the clinical setting. Urinary markers will probably be more sensitive for histological damage, whereas serum levels are more sensitive for clearance changes. In order to define what degree of subclinical damage as detected by biomarkers we will accept we need studies linking acute tubular damage to long-term outcomes.

More published literature has focused on the ability of new biomarkers to predict the development of AKI earlier than serum creatinine [23]. Recent analysis of several prospective observational cohort studies showed that elevations of urine and plasma NGAL predispose patients for the need for renal replacement therapy, increased mortality and longer hospital stays, even without a significant rise in serum creatinine [56]. Ability of new biomarkers to distinguish patients that are at the highest risk of the worst patient outcomes will be of the utmost importance as there is an increased need for more clinical trials for the treatment of AKI [23]. More work needs to be done on assessing the associations between AKI biomarkers and longer-term outcomes such as survival, CKD, and ESRD. In addition, the significance of subclinical AKI (those with increase in biomarkers but no elevation in serum creatinine) needs to be determined. One biomarker may not be enough, some are talking about a set of kidney biomarkers. For instance, the urinary concentration of TIMP-2 and IGFBP7 had the highest predictive value for AKI development when used together [55]. In addition to early diagnosis and prediction, it would be beneficial to identify biomarkers capable of differentiating AKI subtypes, identifying aetiologies, predicting clinical outcomes, allow- 
ing for risk stratification and enabling measuring response to intervention [11]. Researchers in the TRIBE-AKI which is the largest of its kind so far, concluded that prognostic significance of studied biomarkers was less impressive than was previously reported [17].

\section{Disclosure}

Authors report no conflict of interest.

\section{References}

1. Uchino S, Kellum JA, Bellomo R, Doig GS, Morimatsu H, Morgera $S$, Schetz M, Tan I, Bouman C, Macedo E, Gibney N, Tolwani A, Ronco C; Beginning and Ending Supportive Therapy for the Kidney (BEST Kidney) Investigators. Acute renal failure in critically ill patients: a multinational, multicenter study. JAMA 2005; 294: 813-818.

2. Vanmassenhove J, Vanholder R, Nagler E, Van Biesen W. Urinary and serum biomarkers for the diagnosis of acute kidney injury: an in-depth review of the literature. Nephrol Dial Transplant 2013; 28: 254-273.

3. Haase-Fielitz A, Haase M, Devarajan P. Neutrophil gelatinase-associated lipocalin as a biomarker of acute kidney injury: a critical evaluation of current status. Ann Clin Biochem 2014; 51 (Pt 3): 335-351.

4. Ivert T, Holzmann MJ, Sartipy U. Survival in patients with acute kidney injury requiring dialysis after coronary artery bypass grafting. Eur J Cardiothorac Surg 2014; 45: 312-317.

5. Chertow GM, Levy EM, Hammermeister KE, Grover F, Daley J. Independent association between acute renal failure and mortality following cardiac surgery. Am J Med 1998; 104: 343-348.

6. Coca SG, Yusuf B, Shlipak MG, Garg AX, Parikh CR. Long-term risk of mortality and other adverse outcomes after acute kidney injury: a systematic review and meta-analysis. Am J Kidney Dis 2009; 53: 961-973.

7. Kidher E, Harling L, Ashrafian H, Naase H, Chukwuemeka A, Anderson J, Francis DP, Athanasiou T. Pulse wave velocity and neutrophil gelatinaseassociated lipocalin as predictors of acute kidney injury following aortic valve replacement. J Cardiothorac Surg 2014; 9: 89.

8. Mårtensson J, Martling C-R, Bell M. Novel biomarkers of acute kidney injury and failure: clinical applicability. Br J Anaesth 2012; 109: 843-850.

9. Endre ZH. Novel biomarkers of acute kidney injury: time for implementation? Biomark Med 2014; 8: 1185-1188.

10. Arthur JM, Hill EG, Alge JL, Lewis EC, Neely BA, Janech MG, Tumlin JA, Chawla LS, Shaw AD; SAKInet Investigators. Evaluation of 32 urine biomarkers to predict the progression of acute kidney injury after cardiac surgery. Kidney Int 2014; 85: 431-438.

11. Abdallah E, Waked E, Al-Helal B, Asad R, Nabil M, Harba T. Novel troponinlike biomarkers of acute kidney injury. Saudi J Kidney Dis Transpl 2013; 24: 1111-1124.

12. Parikh CR, Thiessen-Philbrook H, Garg AX, Kadiyala D, Shlipak MG, Koyner JL, Edelstein CL, Devarajan P, Patel UD, Zappitelli M, Krawczeski CD, Passik CS, Coca SG; TRIBE-AKI Consortium. Performance of kidney injury molecule-1 and liver fatty acid-binding protein and combined biomarkers of AKI after cardiac surgery. Clin J Am Soc Nephrol 2013; 8: 1079-1088.

13. Devarajan P. Review: neutrophil gelatinase-associated lipocalin: a troponinlike biomarker for human acute kidney injury. Nephrol Carlton Vic 2010; 15: 419-428.

14. Nielsen BS, Borregaard N, Bundgaard JR, Timshel S, Sehested M, Kjeldsen L. Induction of NGAL synthesis in epithelial cells of human colorectal neoplasia and inflammatory bowel diseases. Gut 1996; 38: 414-420.

15. Chakraborty S, Kaur S, Guha S, Batra SK. The multifaceted roles of neutrophil gelatinase associated lipocalin (NGAL) in inflammation and cancer. Biochim Biophys Acta 2012; 1826: 129-169.

16. Endre ZH, Pickering JW, Walker RJ, Devarajan P, Edelstein CL, Bonventre JV, Frampton CM, Bennett MR, Ma Q, Sabbisetti VS, Vaidya VS, Walcher AM, Shaw GM, Henderson SJ, Nejat M, Schollum JB, George PM. Improved performance of urinary biomarkers of acute kidney injury in the critically ill by stratification for injury duration and baseline renal function. Kidney Int 2011; 79: 1119-1130.

17. Parikh CR, Coca SG, Thiessen-Philbrook H, Shlipak MG, Koyner JL, Wang Z, Edelstein CL, Devarajan P, Patel UD, Zappitelli M, Krawczeski CD, Passik CS, Swaminathan M, Garg AX; TRIBE-AKI Consortium. Postoperative biomark- ers predict acute kidney injury and poor outcomes after adult cardiac surgery. J Am Soc Nephrol 2011; 22: 1748-1757.

18. Parikh CR, Devarajan P, Zappitelli M, Sint K, Thiessen-Philbrook H, Li S, Kim RW, Koyner JL, Coca SG, Edelstein CL, Shlipak MG, Garg AX, Krawczeski CD; TRIBE-AKI Consortium. Postoperative biomarkers predict acute kidney injury and poor outcomes after pediatric cardiac surgery. J Am Soc Nephrol 2011; 22: 1737-1747.

19. Krawczeski CD, Goldstein SL, Woo JG, Wang Y, Piyaphanee N, Ma Q, Bennett $M$, Devarajan P. Temporal relationship and predictive value of urinary acute kidney injury biomarkers after pediatric cardiopulmonary bypass. J Am Coll Cardiol 2011; 58: 2301-2309.

20. Jayaraman R, Sunder S, Sathi S, Gupta VK, Sharma N, Kanchi P, Gupta A, Daksh SK, Ram P, Mohamed A. Post cardiac surgery acute kidney injury: a woebegone status rejuvenated by the novel biomarkers. Nephrourol Mon 2014; 6: e19598.

21. Rhee H, Shin N, Shin MJ, Yang BY, Kim IY, Song SH, Lee DW, Lee SB, Kwak IS, Seong EY. High serum and urine neutrophil gelatinaseassociated lipocalin levels are independent predictors of renal progression in patients with immunoglobulin A nephropathy. Korean J Intern Med 2015; 30: 354-361.

22. Urbschat A, Obermüller N, Paulus P, Reissig M, Hadji P, Hofmann R, Geiger $\mathrm{H}$, Gauer S. Upper and lower urinary tract infections can be detected early but not be discriminated by urinary NGAL in adults. Int Urol Nephrol 2014; 46: 2243-2249.

23. Koyner JL, Garg AX, Coca SG, Sint K, Thiessen-Philbrook H, Patel UD, Shlipak MG, Parikh CR; TRIBE-AKI Consortium. Biomarkers predict progression of acute kidney injury after cardiac surgery. J Am Soc Nephrol 2012; 23: 905-914.

24. Shao X, Tian L, Xu W, Zhang Z, Wang C, Qi C, Ni Z, Mou S. Diagnostic value of urinary kidney injury molecule 1 for acute kidney injury: a meta-analysis. PLoS One 2014; 9: e84131.

25. Vaidya VS, Ford GM, Waikar SS, Wang Y, Clement MB, Ramirez V, Glaab WE, Troth SP, Sistare FD, Prozialeck WC, Edwards JR, Bobadilla NA, Mefferd SC, Bonventre JV. A rapid urine test for early detection of kidney injury. Kidney Int 2009; 76: 108-114.

26. Vaidya VS, Ozer JS, Dieterle F, Collings FB, Ramirez V, Troth S, Muniappa N, Thudium D, Gerhold D, Holder DJ, Bobadilla NA, Marrer E, Perentes E, Cor$\operatorname{dier}$ A, Vonderscher J, Maurer G, Goering PL, Sistare FD, Bonventre JV. Kidney injury molecule-1 outperforms traditional biomarkers of kidney injury in preclinical biomarker qualification studies. Nat Biotechnol 2010; 28: 478-485.

27. Shalabi A, Abassi Z, Awad H, Halachmi S, Moskovitz B, Kluger Y, Nativ O. Urinary NGAL and KIM-1: potential association with histopathologic features in patients with renal cell carcinoma. World J Urol 2013; 31: 1541-1545.

28. Faubel S, Edelstein CL. Caspases as drug targets in ischemic organ injury. Curr Drug Targets Immune Endocr Metabol Disord 2005; 5: 269-287.

29. Haase M, Bellomo R, Story D, Davenport P, Haase-Fielitz A. Urinary interleukin-18 does not predict acute kidney injury after adult cardiac surgery: a prospective observational cohort study. Crit Care Lond Engl 2008; 12: R96.

30. Chang CH, Fan PC, Lin CY, Yang CH, Chen YT, Chang SW, Yang HY, Jenq CC, Hung CC, Yang CW, Chen YC. Elevation of Interleukin-18 Correlates With Cardiovascular, Cerebrovascular, and Peripheral Vascular Events: A Cohort Study of Hemodialysis Patients. Medicine (Baltimore) 2015; 94: e1836.

31. Koyner JL, Bennett MR, Worcester EM, Ma Q, Raman J, Jeevanandam V, Kasza KE, O'Connor MF, Konczal DJ, Trevino S, Devarajan P, Murray PT. Urinary cystatin $C$ as an early biomarker of acute kidney injury following adult cardiothoracic surgery. Kidney Int 2008; 74: 1059-1069.

32. Ghonemy TA, Amro GM. Plasma neutrophil gelatinase-associated lipocalin (NGAL) and plasma cystatin C (CysC) as biomarker of acute kidney injury after cardiac surgery. Saudi J Kidney Dis Transpl 2014; 25: 582-588.

33. Spahillari A, Parikh CR, Sint K, Koyner JL, Patel UD, Edelstein CL, Passik CS, Thiessen-Philbrook TH, Swaminathan M, Shlipak MG. Serum cystatin C versus creatinine-based definitions of acute kidney injury following cardiac surgery: a prospective cohort study. Am J Kidney Dis 2012; 60: 922-929.

34. Wald R, Liangos O, Perianayagam MC, Kolyada A, Herget-Rosenthal S, Mazer CD, Jaber BL. Plasma cystatin C and acute kidney injury after cardiopulmonary bypass. Clin J Am Soc Nephrol 2010; 5: 1373-1379.

35. Koyner JL, Garg AX, Shlipak MG, Patel UD, Sint K, Hong K, Devarajan P, Edelstein ChL, Zappitelli M, Thiessen-Philbrook H, Parikh ChR. Urinary cystatin C and acute kidney injury after cardiac surgery. Am J Kidney Dis 2013; 61: 730-738.

36. Hsiao PG, Hsieh CA, Yeh CF, Wu HH, Shiu TF, Chen YC, Chu PH. Early prediction of acute kidney injury in patients with acute myocardial injury. J Crit Care 2012; 27: 525.e1-7. 
37. Yim H, Kym D, Seo DK, Yoon J, Yang H-T, Lee J, Cho YS, Hur J, Chun W, Han SW. Serum cystatin $C$ and microalbuminuria in burn patients with acute kidney injury. Eur J Clin Invest 2015; 45: 594-600.

38. Wang Y, Cao X, Yang P, Chen M, Chen Z. Association of metabolic syndrome with serum cystatin $C$ in people undergoing health examination. Zhong Nan Da Xue Xue Bao Yi Xue Ban 2015; 40: 742-747 [Article in Chinese].

39. Wetz AJ, Richardt EM, Wand S, Kunze N, Schotola H, Quintel M, Bräuer A, Moerer O. Quantification of urinary TIMP-2 and IGFBP-7: an adequate diagnostic test to predict acute kidney injury after cardiac surgery? Crit Care 2015; 19: 3.

40. Meersch M, Schmidt C, Van Aken H, Martens S, Rossaint J, Singbartl K, Görlich D, Kellum JA, Zarbock A. Urinary TIMP-2 and IGFBP7 as early biomarkers of acute kidney injury and renal recovery following cardiac surgery. PLoS One 2014; 9: e93460.

41. Westhoff JH, Tönshoff B, Waldherr S, Pöschl J, Teufel U, Westhoff TH, Fichtner A. Urinary Tissue Inhibitor of Metalloproteinase-2 (TIMP-2) • InsulinLike Growth Factor-Binding Protein 7 (IGFBP7) Predicts Adverse Outcome in Pediatric Acute Kidney Injury. PLoS One 2015; 10: e0143628.

42. Bell M, Larsson A, Venge P, Bellomo R, Mårtensson J. Assessment of cellcycle arrest biomarkers to predict early and delayed acute kidney injury. Dis Markers 2015; 2015: 158658.

43. Oyama Y, Takeda T, Hama H, Tanuma A, lino N, Sato K, Kaseda R, Ma M, Yamamoto T, Fujii H, Kazama JJ, Odani S, Terada Y, Mizuta K, Gejyo F, Saito A. Evidence for megalin-mediated proximal tubular uptake of L-FABP, a carrier of potentially nephrotoxic molecules. Lab Invest 2005; 85: 522-531.

44. Devarajan P. Emerging urinary biomarkers in the diagnosis of acute kidney injury. Expert Opin Med Diagn 2008; 2: 387-398.

45. Hu MC, Moe OW. Klotho as a potential biomarker and therapy for acute kidney injury. Nat Rev Nephrol 2012; 8: 423-429.

46. Burke-Gaffney A, Svermova T, Mumby S, Finney SJ, Evans TW. Raised plasma Robo4 and cardiac surgery-associated acute kidney injury. PLoS One 2014; 9: e111459.

47. Ranganathan P, Jayakumar C, Mohamed R, Weintraub NL, Ramesh G. Semaphorin $3 \mathrm{~A}$ inactivation suppresses ischemia-reperfusion-induced inflammation and acute kidney injury. Am J Physiol Renal Physiol 2014; 307: F183-194.

48. Doi K, Noiri E, Nangaku M, Yahagi N, Jayakumar C, Ramesh G. Repulsive guidance cue semaphorin $3 \mathrm{~A}$ in urine predicts the progression of acute kidney injury in adult patients from a mixed intensive care unit. Nephrol Dial Transplant 2014; 29: 73-80.

49. Jayakumar C, Ranganathan P, Devarajan P, Krawczeski CD, Looney S, Ramesh $G$. Semaphorin $3 A$ is a new early diagnostic biomarker of experimental and pediatric acute kidney injury. PLoS One 2013; 8: e58446.

50. Jayakumar C, Nauta FL, Bakker SJL, Bilo H, Gansevoort RT, Johnson MH, Ramesh G. Netrin-1, a urinary proximal tubular injury marker, is elevated early in the time course of human diabetes. J Nephrol 2014; 27: 151-157.

51. Tu Y, Wang H, Sun R, Ni Y, Ma L, Xv F, Hu X, Jiang L, Wu A, Chen X, Chen M, Liu J, Han F. Urinary netrin-1 and KIM-1 as early biomarkers for septic acute kidney injury. Ren Fail 2014; 36: 1559-1563.

52. Ramesh G, Krawczeski CD, Woo JG, Wang Y, Devarajan P. Urinary Netrin-1 Is an Early Predictive Biomarker of Acute Kidney Injury after Cardiac Surgery. Clin J Am Soc Nephrol 2010; 5: 395-401.

53. Chen Y, Du XY. Functional properties and intracellular signaling of CCN1/ Cyr61. J Cell Biochem 2007; 100: 1337-1345.

54. Lai CF, Lin SL, Chiang WC, Chen YM, Wu VC, Young GH, Ko WJ, Kuo ML, Tsai TJ, Wu KD. Blockade of cysteine-rich protein 61 attenuates renal inflammation and fibrosis after ischemic kidney injury. Am J Physiol Renal Physiol 2014; 307: F581-592.

55. Kashani K, Al-Khafaji A, Ardiles T, Artigas A, Bagshaw SM, Bell M, Biho$\operatorname{rac} A$, Birkhahn R, Cely CM, Chawla LS, Davison DL, Feldkamp T, Forni LG, Gong MN, Gunnerson KJ, Haase M, Hackett J, Honore PM, Hoste EA, Joannes-Boyau O, Joannidis M, Kim P, Koyner JL, Laskowitz DT, Lissauer ME, Marx G, McCullough PA, Mullaney S, Ostermann M, Rimmelé T, Shapiro NI, Shaw AD, Shi J, Sprague AM, Vincent JL, Vinsonneau C, Wagner L, Walker MG, Wilkerson RG, Zacharowski K, Kellum JA. Discovery and validation of cell cycle arrest biomarkers in human acute kidney injury. Crit Care 2013; 17: R25.

56. Haase M, Devarajan P, Haase-Fielitz A, Bellomo R, Cruz DN, Wagener G, Krawczeski CD, Koyner JL, Murray P, Zappitelli M, Goldstein SL, Makris K, Ronco C, Martensson J, Martling CR, Venge P, Siew E, Ware LB, Ikizler TA, Mertens PR. The outcome of neutrophil gelatinase-associated lipocalinpositive subclinical acute kidney injury: a multicenter pooled analysis of prospective studies. J Am Coll Cardiol 2011; 57: 17. 